\title{
QUALITY INVESTIGATION OF FROZEN GARDEN STRAWBERRIES AT PARTIAL DEHYDRATION BEFORE FREEZING
}

\author{
Iryna Zamorska \\ Department of Technology Storage and Processing of Fruits and Vegetables ${ }^{1}$ \\ zil197608@gmail.com \\ Volodymyr Zamorskyi \\ Department of Fruit Growing and Viticulture \\ volzam55@gmail.com \\ Yuliya Halahur \\ Department of Management ${ }^{1}$ \\ yuliya.zborovska@gmail.com \\ Viktor Osyka \\ Faculty of Trade and Marketing ${ }^{2}$ \\ osyka@knteu.kiev.ua \\ Svitlana Belinska \\ Department of commodity science, safety and quality management ${ }^{2}$ \\ belinskas@ukr.net \\ Iuliia Motuzka \\ Department of commodity science, safety and quality management ${ }^{2}$ \\ unmot@ukr.net \\ Tetiiana Bozhko \\ Department of commodity science, safety and quality management ${ }^{2}$ \\ tatyana_bozhko@ukr.net \\ Olena Krasulya \\ Department of milk and dairy products technology \\ National University of Food Technologies \\ 68 Volodymyrska str., Kyiv, Ukraine, 03680 \\ olena_krasulya@ukr.net \\ Mariia Fil \\ Department of Tourism \\ Ivan Franko National University of Lviv \\ 41 P. Doroshenko str., Lviv, Ukraine, 79000 \\ merifil.ua@gmail.com \\ ${ }^{1}$ Uman National University of Horticulture \\ 1 Instutytska str., Uman, Ukraine, 20300 \\ ${ }^{2}$ Kyiv National University of Trade and Economics \\ 19 Kioto str., Kyiv, Ukraine, 02156
}

\footnotetext{
Abstract

Garden strawberry is an important berry culture, consumed fresh and frozen. But a quality of frozen berries is not always at the high level because of changing organoleptic properties, tissues structure and biological active substances losses. It motivates searches for different methods of previous processing of berries before freezing. There was used a production technology of frozen strawberry with partial dehydration before freezing for solving the problem.
} 
Garden strawberries of varieties Rusanivka, Honey and Polka were dried on air before freezing ("control" variant), and another part was partially dehydrated in a drying chamber at temperature $40{ }^{\circ} \mathrm{C}$ during $30 \mathrm{~min}$ ("partial dehydration” variant) with further freezing to final temperature $-18^{\circ} \mathrm{C}$, with packing in packages of polyethylene film with a mass up to $500 \mathrm{~g}$ and storing in a refrigerator at temperature $-18^{\circ} \mathrm{C}$ during 6 months. There were studied main parameters of the chemical composition of fresh and frozen strawberries: content of dry soluble substances, sugars, organic acids, ascorbic acid and sugar-acidic index. Organoleptic quality parameters of frozen strawberries were assessed by the 5-point scale. The experiment was repeated trice.

It has been established, that frozen strawberries, partially dehydrated before freezing, saved by $0.2-0.3 \%$ more dry soluble substances, by $0.2 \%$ - sugars, by $7.0-7.9 \%$ - ascorbic acid at a practically equal level of organic acids.

The organoleptic mark of frozen partially dehydrated strawberries was by $0.2-0.3$ points higher against the control. Among the studied varieties of strawberry, Polka berries got a mark higher by $0.2-0.9$ points.

Keywords: strawberries, partial dehydration, freezing of garden strawberry.

DOI: $10.21303 / 2504-5695.2020 .001051$

\section{Introduction}

Garden strawberry is a leading berry culture in the world, which production volumes in 2017, according to data of the Britain analytic company Fresh4cast, reached $9.7 \mathrm{mln}$ tons that was $72 \%$ of the world production of berries, with a prognosis for 2020 as up to $15.4 \mathrm{mln}$ tons [1, 2].

Garden strawberry is highly appreciated by consumers because of the pleasant outlook, harmonic taste and smell, essential amount of sugars, organic acids, vitamins, mineral compounds $[3,4]$. Garden strawberry is consumed fresh, frozen and as other processing products.

Fast freezing as a preserving way favors the maximal saving of initial properties of raw materials, but a quality of frozen strawberry not always satisfies consumers' requirements. This fact is conditioned by changing organoleptic parameters and microstructure of berries' tissue as a result of recrystallization. The essential demand for frozen strawberry at world and Ukrainian markets stimulates searching for methods of its preliminary processing before breezing that maximally favor berries' natural properties preservation.

For stabilizing a quality of frozen strawberry, there are recommended solutions with antioxidizing, antiseptic properties that favor preservation of $\mathrm{C}$-vitamin value, among which aqueous extracts from oak bark, birch, tutsan grass and green tea infusion [4], concentrated solutions of saccharose with cryoprotective properties [5]. The positive influence on preservation of the strawberry tissue microstructure is made by solutions of calcium chloride $\left(\mathrm{CaCl}_{2}\right)$ and pectin methyl esterase, $0.3 \%$ guar gum and $2 \%$ sugar-pectin [6-8]. But at these methods of preliminary processing of strawberries before freezing, there appears a necessity to buy auxiliary materials, not always easily accessible.

This all allows to state that studies, devoted to a quality of frozen garden strawberries at different methods of preliminary processing before freezing, are expedient.

For solving the quality problem of frozen strawberry, we offered partial dehydration of berries before freezing that favors getting more concentrated products, saving the tissue structure, inactivation of oxidizing-renewing components and decreasing storage duration.

The aim of the work was to study a quality of frozen garden strawberry at partial dehydration of berries before freezing by the complex of physical-chemical and organoleptic parameters that allows to improve a quality of frozen strawberry.

The following tasks were solved for attaining this aim:

- to asses an influence of partial dehydration of strawberries before freezing on changes of physical-chemical quality parameters, based on experimental studies;

- to assess organoleptic quality parameters of frozen strawberries at partial dehydration before freezing.

\section{Materials and Methods}

The studies were conducted in 2015-2016 at the department of storage and processing of fruits and vegetables of the Uman national university of gardening, Uman, Ukraine. Strawberries 
Rusanivka, Honey and Polka, cultivated by the traditional technology, were harvested at the consumption ripeness stage and immediately transported to the laboratory. Strawberries were prepared for freezing according to the technological instruction for producing fast-frozen fruits and berries: sorted, cleaned from pedicles and sepals, washed, dried and frozen scattering up to final temperature within berries $-18{ }^{\circ} \mathrm{C}$, packed in packages of polyethylene film for food products with a mass up to $500 \mathrm{~g}$ and stored in a refrigerator at temperature $-18^{\circ} \mathrm{C}$ during 6 months. The experiment was repeated trice.

\section{Experimental procedures}

A part of strawberries was dried on air ("control" variant), and another part was partially dehydrated in a drying chamber at temperature $40{ }^{\circ} \mathrm{C}$ during $30 \mathrm{~min}$ ("partial dehydration" variant) that gives a possibility to evaporate an essential amount of moisture, without excessive drying of berries. Control and experimental samples of strawberries wee frozen in the aerial medium to final temperature $-18{ }^{\circ} \mathrm{C}$ (according to the technological instruction for producing fast-frozen fruits and berries). Frozen strawberry was packed in packages of polyethylene film for food products with a mass up to $500 \mathrm{~g}$ and stored in a refrigerator at temperature $-18{ }^{\circ} \mathrm{C}$ during 6 months (according to the technological instruction for producing fast-frozen fruits and berries). The experiment was repeated trice.

A content of dry soluble substances was determined in fresh and frozen strawberries by the electric refractometer of Pal-1 type (Japan), sugars - by the spectrophotomeric method [9, 10], titrated acids - by alkali titration [10], ascorbic acid - by Tillmans method [11]. Orhanoleptic quality parameters of frozen strawberry were assessed by the 5-point scale. 10 testers assessed them by parameters of outlook, consistence, color, taste, smell and general estimation. Strawberries, frozen without partial dehydration before freezing, were accepted as a control.

The statistical analysis was conducted, using the program StatSoft STATISTICA 6.1.478 Russian, Enterprise Single User (2007).

\section{Results and Discussion}

The studies have established (Fig. 1), that strawberries of different pomoloogic varieties accumulated in their composition from 9.3 to $9.8 \%$ of dry soluble substances with the essential advantage of Polka ones.

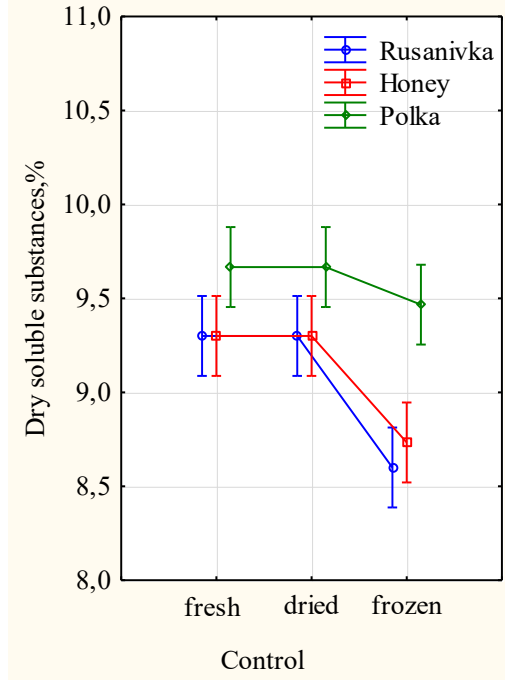

$a$

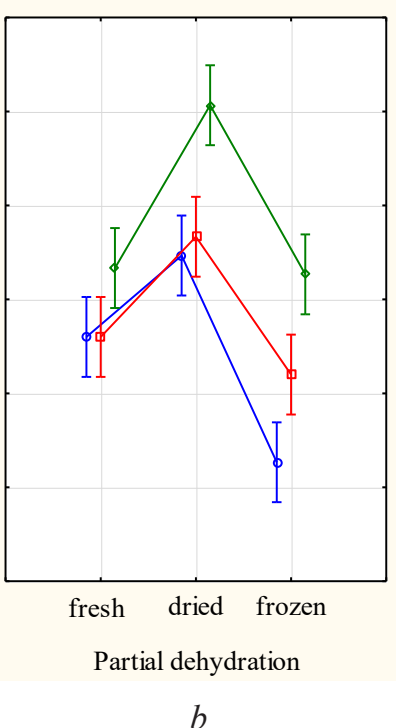

$b$

Fig. 1. Content of dry soluble substances in garden strawberries depending on variety, preliminary processing and freezing: $a$-control; $b$-with partial dehydration 
Preliminary drying of strawberry on air didn't influence a content of dry soluble substances in them, whereas this index in partially dehydrated berries increased by $0.4-0.6 \%$ depending on variety that is conditioned by partial evaporation of moisture from the product. It must be noted, that the high level of dry soluble substances was saved by Polka berries.

It is known, that just at the stage of freezing main changes of the chemical composition of raw materials take place that is proved by the research results: losses of soluble dry substances were $0.8-1.2 \%$ from their content after preliminary drying. Moreover, in the control they were higher by $0.2-0.3 \%$. The essential losses of dry soluble substances were revealed in Honey berries, frozen without partial dehydration $-1.2 \%$.

The content of sugars in fresh strawberries of the studied varieties varied within $6.9-7.8 \%$. By $0.5-0.9 \%$ higher saccharinity was revealed in Polka strawberries (Fig. 2), that is testified by variety peculiarities of berries.

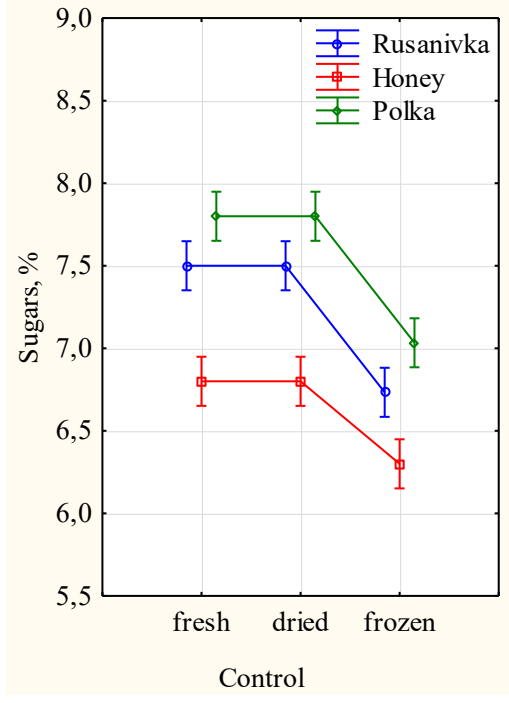

$a$

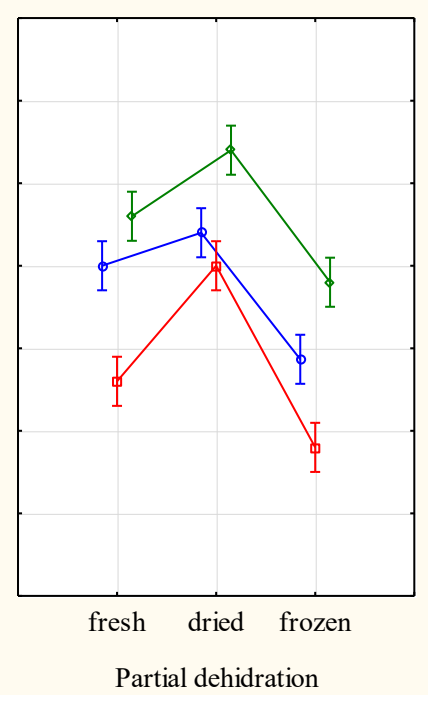

$b$

Fig. 2. Content of sugars in garden strawberries depending on variety, preliminary processing and freezing: $a$-control; $b$ - with partial dehydration

Partial dehydration of berries before freezing favored the growth of the sugars content in them by $0.3-0.6 \%$, and after freezing - vice versa. Their level essentially decreased (by $0.7-1.2 \%$ ) with losses, higher by $0.2 \%$ in the control.

The acidity of strawberries was established at level $0.9-1.0 \%$, moreover their higher level $1 \%$ was established in Honey berries (Fig. 3), that is conditioned by variety peculiarities.

As a result of partial dehydration of berries, the content of organic acids in them decreased by $0.2-0.3 \%$ from the initial, whereas no changes were revealed in the control.

On the contrary, during freezing of berries the level of organic acids grew in practically all variants of the experiment - by $0.1-0, \%$, that is a special feature of frozen strawberry.

The sugar-acid index of strawberries of the studied varieties was established at level 6.9-8.7, that, according to W. Wozniak [12], allows to consider the taste of berries as sweet. The low sugar-acidic index was inherent to Honey strawberries; this fact is conditioned by the low sugars level (Fig. 4).

As a result of partial dehydration, the sugar-acidic index of berries grew by 2.5-4.6 units and reached value 9.4-12.8 due to the change of the ratio between sugars and organic acids in berries. The decrease of the index by 2.1-5.2 units was observed in frozen berries, with the essential one in Rusanivka ones, that is conditioned by essential losses of sugars.

The antioxidant activity of garden strawberries is mainly determined by a content of ascorbic acid in them [13]. At freezing there are observed losses of ascorbic acid at the expanse of its oxidation to dehydroascorbic one [14]. 


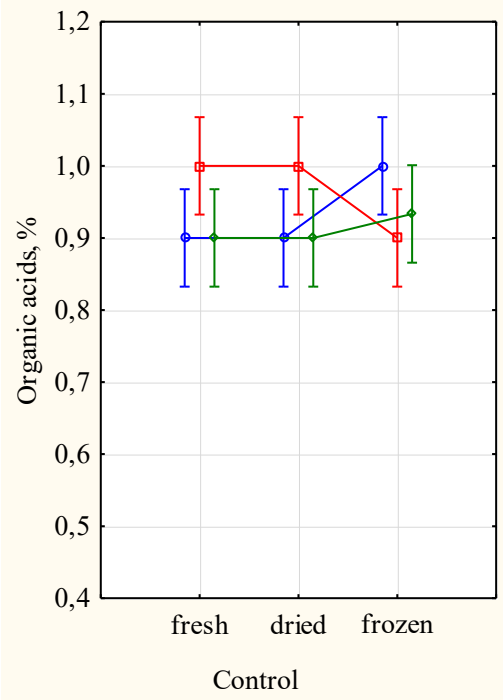

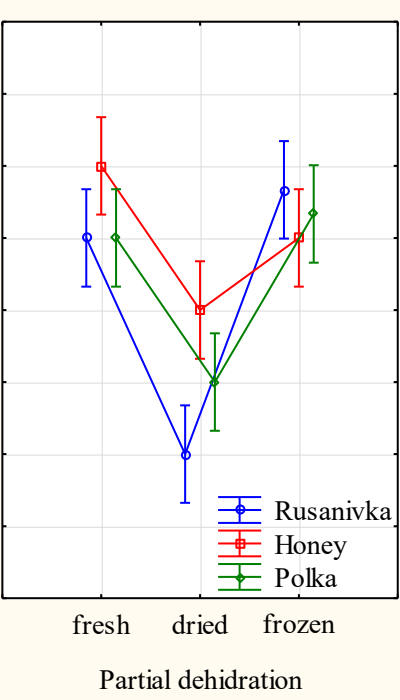

$b$

Fig. 3. Content of organic acids in garden strawberries depending on variety, preliminary processing and freezing: $a$-control; $b$ - with partial dehydration

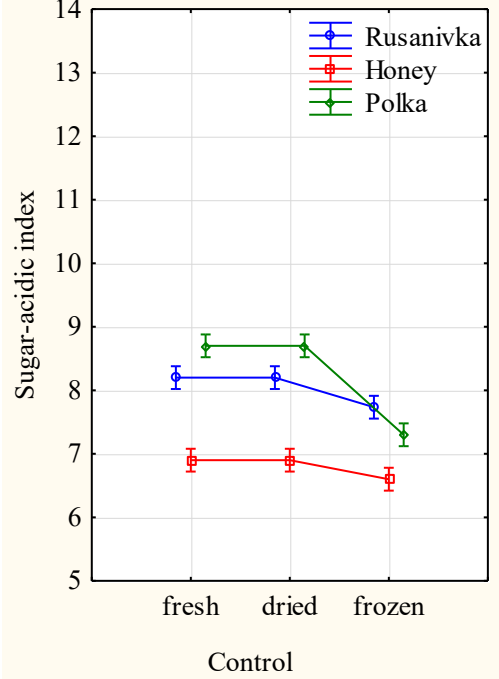

$a$

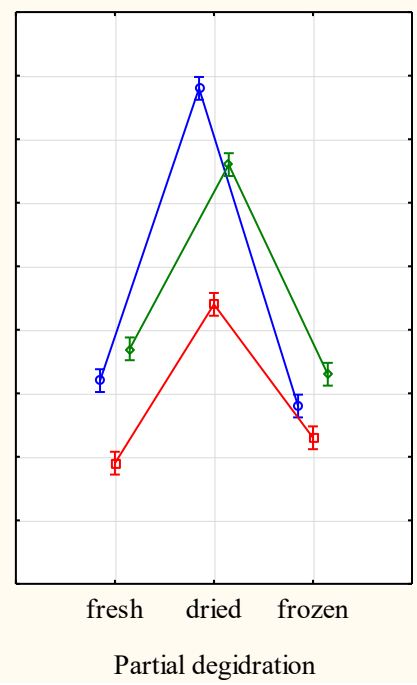

$b$

Fig. 4. Sugar-acidic index of garden strawberries depending on variety, preliminary processing and freezing: $a-$ control; $b$ - with partial dehydration

It has been established, that fresh Honey strawberries differed by the content of ascorbic acid $-105.1 \mathrm{mg} / 100 \mathrm{~g}$ (Fig. 5), that is a special feature of this variety. As a result of partial dehydration of berries, the losses of ascorbic acid were $6.8-12.3 \%$ of the initial content, whereas no losses were revealed in the control.

As a result of freezing, the content of ascorbic acid in berries decreased by $4.3-12.6 \%$ more. In the experimental variants without partial dehydration the losses were by $7.0-7.9 \%$ higher. Honey strawberries had the losses at level 5.2-12.6\%.

At freezing, storage of frozen products and as a result of defrost, there are changes of their organoleptic properties, conditioned by the activity of enzymes. Undesirable changes of the consistence, color, taste and smell of defrost vegetable raw materials are connected with their activity [15]. 
The organoleptic parameters of defrost berries are presented on Fig. 6. The outlook of frozen strawberries was estimated as 3.8-4.8 points. Samples of partially dehydrated berries received by $0.2-0.3$ points higher mark. The analogous data were obtained also at assessing the consistence of frozen strawberries that testifies to higher water-retaining capacity of partially dehydrated berries at freezing.

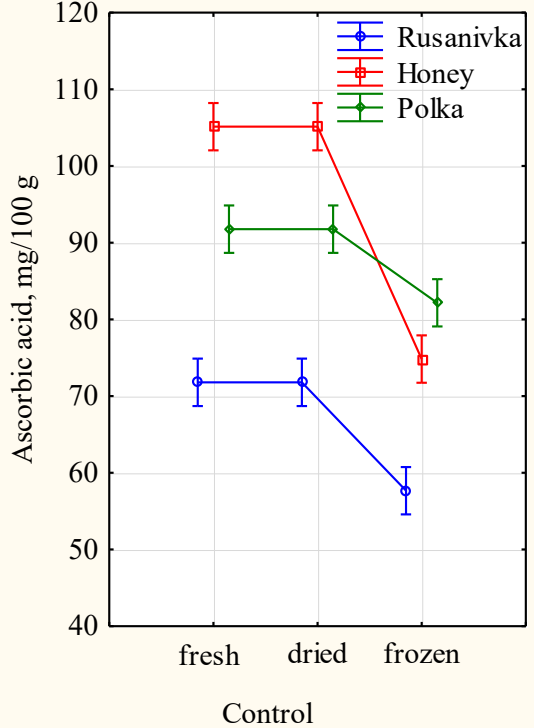

$a$

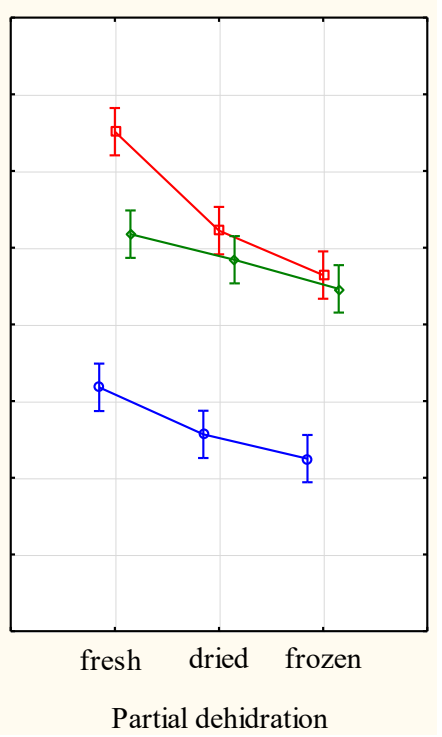

$b$

Fig. 5. Content of ascorbic acid in garden strawberries depending on variety, preliminary processing and freezing: $a$ - control; $b$-with partial dehydration

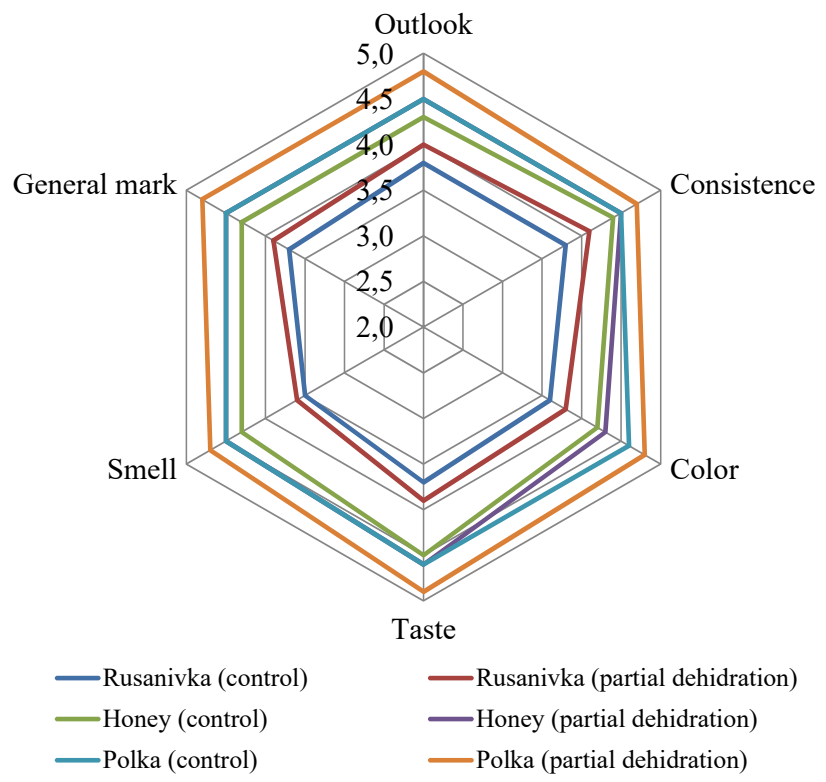

Fig. 6. Organoleptic assessment of frozen garden strawberries

The color and taste of frozen strawberries were assessed by testers as 3.6-4.8 and 3.74.9 points, respectively.

It is known, that the process of freezing causes changes of the aromatic profile of strawberries [16]. The worsening of the smell of frozen berries is observed also at storage at the expanse of the decreasing content of esters at the constant influence of carbonyl compounds [16]. The use 
of partial dehydration of berries before freezing favored the preservation of their smell. In general the quality of strawberries, partially dehydrated before freezing, is estimated higher. Among the studied varieties, Polka berries received the mark, by $0.2-0.9$ points higher.

\section{Conclusions}

The use of partial dehydration of berries before freezing favors the preservation of main components of the chemical composition, vitamin value and increases the organoleptic mark. Partially dehydrated frozen Polka berries have the higher quality. The further studies will be directed at studying the suitableness of different pomologic garden strawberry varieties for freezing at partial dehydration.

\section{References}

[1] 72\% svitovoho vyrobnytstva yahid u 2017 rotsi prypalo na sunytsiu sadovu. Available at: https://info.shuvar.com/ news/2647/72proc-svitovoho-vyrobnytstva-yahid-u-2017-rotsi-prypalo-na-sunytsyu-sadovu

[2] Kratkiy analiz rynka zemlyaniki v Ukraine za 2015-16 gody. Available at: http://yagodovod.com/articles/323-kratkii-analizrynka-zemljaniki-v-ukraine-za-2015-16-gody.html

[3] Yan, J., Ban, Z., Lu, H., Li, D., Poverenov, E., Luo, Z., Li, L. (2018). The aroma volatile repertoire in strawberry fruit: a review. Journal of the Science of Food and Agriculture, 98 (12), 4395-4402. doi: https://doi.org/10.1002/jsfa.9039

[4] Parra-Palma, C., Úbeda, C., Gil, M., Ramos, P., Castro, R. I., Morales-Quintana, L. (2019). Comparative study of the volatile organic compounds of four strawberry cultivars and it relation to alcohol acyltransferase enzymatic activity. Scientia Horticulturae, 251, 65-72. doi: https://doi.org/10.1016/j.scienta.2019.03.017

[5] Gribova, N. A., Berketova, L. V. (2018). Osmotic dehydration of berries: study of mass transfer parameters. Proceedings of the Voronezh State University of Engineering Technologies, 80 (2), 30-37. doi: https://oi.org/10.20914/2310-1202-2018-2-30-37

[6] Zamorska, I. (2018). Change of the main components of a chemical composition of frozen strawberries under previous treatment in solutions with structure-retaining properties. Bulletin of the National Technical University «KhPI» Series: New Solutions in Modern Technologies, 2 (26 (1302)), 61-65. doi: https://doi.org/10.20998/2413-4295.2018.26.33

[7] Galetto, C. D., Verdini, R. A., Zorrilla, S. E., Rubiolo, A. C. (2010). Freezing of strawberries by immersion in CaCl2 solutions. Food Chemistry, 123 (2), 243-248. doi: https://doi.org/10.1016/j.foodchem.2010.04.018

[8] Zamorska, I. (2017). Cryoresistance and height index of frozen strawberries pretreated in the solutions with structure-maintaining properties. Bulletin of the National Technical University «KhPI» Series: New Solutions in Modern Technologies, 53 (1274), 72-76. doi: https://doi.org/10.20998/2413-4295.2017.53.11

[9] Jham, G. N., Fernandes, S. A., Garcia, C. F., Silva, A. A. da. (2002). Comparison of GC and HPLC for the quantification of organic acids in coffee. Phytochemical Analysis, 13 (2), 99-104. doi: https://doi.org/10.1002/pca.629

[10] AOAC International (1995). Official Methods of Analysis of AOAC International. Secs. 942.15. Washington.

[11] AOAC International (2002). Official Methods of Analysis of AOAC International. Secs. 967.21. Washington. USA.

[12] Ikegaya, A., Toyoizumi, T., Ohba, S., Nakajima, T., Kawata, T., Ito, S., Arai, E. (2019). Effects of distribution of sugars and organic acids on the taste of strawberries. Food Science \& Nutrition, 7 (7), 2419-2426. doi: https://doi.org/10.1002/fsn3.1109

[13] Zhao, H., Liu, S., Chen, M., Li, J., Huang, D., Zhu, S. (2019). Synergistic effects of ascorbic acid and plant-derived ceramide to enhance storability and boost antioxidant systems of postharvest strawberries. Journal of the Science of Food and Agriculture, 99 (14), 6562-6571. doi: https://doi.org/10.1002/jsfa.9937

[14] Bulut, M., Bayer, Ö., Kırt1l, E., Bayındırl1, A. (2018). Effect of freezing rate and storage on the texture and quality parameters of strawberry and green bean frozen in home type freezer. International Journal of Refrigeration, 88, 360-369. doi: https:// doi.org/10.1016/j.ijrefrig.2018.02.030

[15] Kobayashi, R., Suzuki, T. (2019). Effect of supercooling accompanying the freezing process on ice crystals and the quality of frozen strawberry tissue. International Journal of Refrigeration, 99, 94-100. doi: https://doi.org/10.1016/j.ijrefrig.2018.11.045

[16] Gonçalves, G. A. S., Resende, N. S., Carvalho, E. E. N., de Resende, J. V., Vilas Boas, E. V. de B. (2017). Physicochemical and volatile profile alterations in pasteurized and frozen strawberry pulp during storage. Journal of Food Processing and Preservation, 42 (1), e13317. doi: https://doi.org/10.1111/jfpp.13317 